\title{
DECLARATION
}

"The work described in this thesis was carried out by me under the supervision of Prof. A Bamunuarachchi (Dept. of Chemistry, University of Sri Jayawardenepura, Nugegoda, Sri Lanka), Dr. W M K Perera (Head, Institute of Post Harvest Technology, National Aquatic Resources Research \& Development Agency, Colombo-15, Sri Lanka) and Dr. V K Graffham (Natural Resources International, The University of Greenwich, Kent, United Kingdom) and the report on this has not been submitted to any university for another degree".

Date $20 / 20+/ 1999$

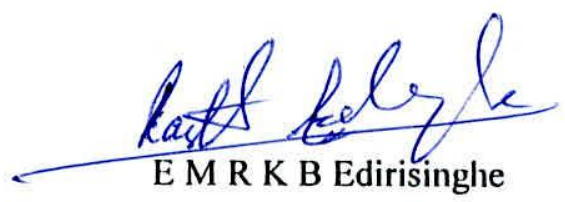




\section{DECLARATION OF THE SUPERVISORS}

"We certify that the above statement made by the candidate is true and that this thesis is suitable for submission to the University for the purpose of evaluation"

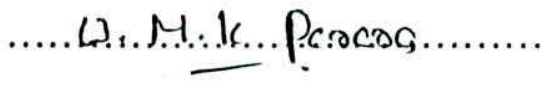

\section{Dr W M K Perera}

Supervisor / Senior Research Officer Institute of Post harvest Technology

National Aquatic Resources Research \& Development Agency (NARA)

Crow Island

Colombo 15

Sri Lanka

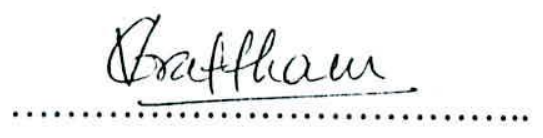

\section{Dr V K Graffham}

Supervisor / Programme Co-ordinator Crop Post Harvest Programme

Natural Resources International (NRIL)

Central Avenue

Chatham Maritime

Kent ME4 4TB

United Kingdom

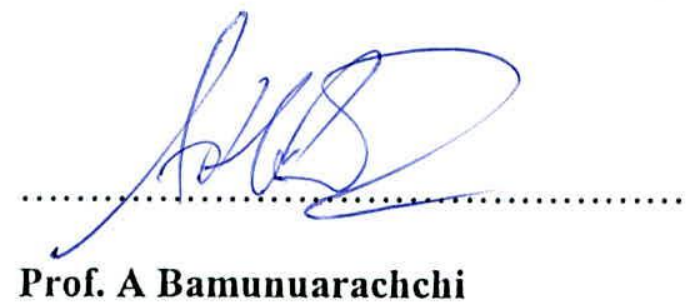

Supervisor / Professor of Applied Chemistry

Department of Chemistry

University of Sri Jayawardenapura

Gangodawila

Nugegoda

Sri Lanka 
COMPOSITION AND STABILITY OF FISH LIPIDS

By

EDIRISINGHE MUDIYANSELAGE RANJITH KEERTHI BANDARA EDIRISINGHE \{B.Sc. Special (Chemistry)\}

Thesis submitted to the University of Sri Jayawardenepura for the award of the Degree of Master of Philosophy in Chemistry on 20 th August 1999 


\section{CONTENTS}

Page No

I. LIST OF TABLES vii

II. LIST OF FIGURES $\mathrm{x}$

III. LIST OF APPENDICES X xii

IV. LIST OF PLATES xii

V. ACKNOWLEDGEMENTS - xiii

VI. ABSTRACT $\quad \mathrm{xv}$

1. INTRODUCTION 1

2. LITERATURE REVIEW 4

2.1. Composition of Fish Lipids 4

2.1.1. Fatty acids 5

2.1.2. Neutral lipids 8

$\begin{array}{ll}\text { 2.1.3. Polar lipids } & 10\end{array}$

2.2. Distribution of Lipids in Fish 12

2.3. Extraction Modification and Utilization of Fish Lipids 14

2.3.1. Extraction of fish lipids $\quad 14$

2.3.2. Modification of fish lipids 15

2.3.3. Utilization of fish lipids 16

2.4. Analysis of Composition and Quality of Fish Lipids 18

2.4.1. Isolation and purification of fish lipids 18

2.4.2. Determination of lipid classes and fatty acid profile 20

2.4.3. Determination of quality of the fish lipids 25 
2.5. Nutritional and Pharmaceutical Importance of Fish Lipids

2.5.1. Fatty acids

2.5.2. Cholesterol

2.5.3. Vitamins

2.5.4. Calorific value

2.6. Changes in the Lipids

2.6.1. Lipid autoxidation

2.6.2. Photooxygenation 35

2.6.3. Lipid autolysis 39

2.6.4. Interaction between lipids and proteins 41

2.7. Preservation of Lipids 42

2.7.1. Storage at low temperature 43

2.7.2. Packaging 43

2.7.3. Uses of antioxidants in preservation of fish lipids

3. EXPERIMENTAL

3.1. Proximate Composition of Fish 52

3.1.1. Determination of moisture 52

3.1.1.1. Materials 52

3.1.1.2. Method 52

3.1.2. Determination of ash 53

3.1.2.1. Materials 53

3.1.2.2. Method 53

3.1.3. Determination of lipid 54

3.1.3.1. Materials 54

3.1.3.2. Method 54

3.1.4. Determination of protein 55

3.1.4.1. Materials 55

3.1.4.2. Method 56 
3.2. Extraction and Quality Determination of Fish Lipids

3.2.1. Extraction of fish lipids 57

3.2.1.1. Extraction by wet rendering 57

3.2.1.1.1. Materials 57

3.2.1.1.2. Method 58

3.2.1.2. Extraction by steaming 58

3.2.1.2.1. Materials 58

3.2.1.2.2. Method 58

3.2.1.3. Acid silage extraction 58

3.2.1.3.1. Materials 58

3.2.1.3.2. Method 59

3.2.1.4. Microbial silage extraction $\quad 59$

3.2.1.4.1. Materials 59

3.2.1.4.2. Method 59

3.2.1.5. Bligh \& Dyer extraction 60

3.2.1.5.1. Materials 60

3.2.1.5.2. Method 60

3.2.2. Determination of quality of extracted fish lipids 60

3.2.2.1. Determination of peroxide value 60

3.2.2.1.1. Materials 60

3.2.2.1.2. Method 61

3.2.2.2. Determination of free fatty acid value 62

3.2.2.2.1. Materials 62

3.2.2.2.2. Method 62

3.2.2.3. Determination of iodine value 63

3.2.2.3.1. Materials 63

3.2.2.3.2. Method 63

3.2.2.4. Determination of fatty acid composition 64

3.2.2.4.1. Materials 64

3.2.2.4.2. Method 65 
3.3. Lipid and Fatty Acid Composition of Selected Fish

$\begin{array}{ll}\text { 3.3.1. Materials } & 67\end{array}$

3.3.2. Method 67

3.4. Fatty Acid Composition (Total) of Small Pelagics 69

$\begin{array}{lll}\text { 3.4.1. Materials } & 69\end{array}$

$\begin{array}{ll}\text { 3.4.2. Method } & 69\end{array}$

3.5. Seasonal Variation of Quality and Quantity of Fish Lipids in 70

Selected Species

$\begin{array}{lll}\text { 3.5.1. Materials } & 70\end{array}$

$\begin{array}{ll}\text { 3.5.2. Method } & 70\end{array}$

3.6. Quality Changes of Fish and Fish Lipids During Storage 71

3.6.1. Storage of fish and fish lipids at room temperature $\left(32^{\circ} \pm 1 \mathrm{C}\right) \quad 71$

3.6.1.1. Materials 71

3.6.1.2. Method 71

3.6.2. Storage of fish in ice $\left(0^{\circ} \pm 1 \mathrm{C}\right) \quad 72$

3.6.2.1. Materials 72

$\begin{array}{lll}\text { 3.6.2.2. Method } & 72\end{array}$

3.6.3. Storage of fish and fish lipids in freezer $\left(-18^{\circ} \pm 1 \mathrm{C}\right)$

$\begin{array}{lll}\text { 3.6.3.1. Materials } & 73\end{array}$

3.6.3.2. Method 73

3.6.4. Determination of total volatile bases (TVB) by 74

Conway-Byrnes method

$\begin{array}{lll}\text { 3.6.4.1. Materials } & 74\end{array}$

3.6.4.2. Method 75

3.7. Preservation of Fish Lipids Using Natural Anti-oxidants 76

3.7.1. Studies on the efficiency of some natural plant product 76 extracts in the preservation of fish lipids.

$\begin{array}{lll}\text { 3.7.1.1 Materials } & 76\end{array}$

$\begin{array}{lll}\text { 3.7.1.2. } & \text { Methods } & 77\end{array}$ 
3.7.2. Quantification of preservative action of crude

Indian gooseberry extract

$\begin{array}{lll}\text { 3.7.2.1. Materials } & 78\end{array}$

3.7.2.1. Method 78

3.7.3. Evaluation of anti-oxidant activity of Indian gooseberry 79 using different solvent systems

$\begin{array}{lll}\text { 3.7.3.1. Materials } & 79\end{array}$

$\begin{array}{lll}\text { 3.7.3.2. Method } & 79\end{array}$

3.7.4. Purification of crude Indian gooseberry extract and the 80 examination of preservative action of purified fractions

$\begin{array}{lll}\text { 3.7.4.1. } & \text { Materials } & 80\end{array}$

$\begin{array}{ll}\text { 3.7.4.2. Method } & 81\end{array}$

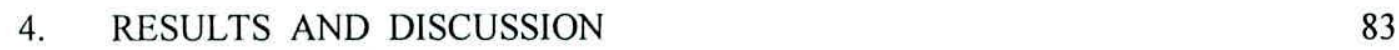

4.1. Proximate Composition of Fish 83

4.1.1 Moisture content 83

4.1.2. Ash content 83

4.1.3. Lipid content $\quad 84$

4.1.4. Protein content $\quad 85$

4.2. Extraction and Quality Determination of Fish Lipids 88

4.3. Lipid and Fatty Acid Composition of Selected Fish 94

4.3.1. Lipid composition of selected fish species 94

4.3.2. Fatty acid composition of lipid classes of White sardinella 96

4.4. Fatty Acid Composition of Small Pelagics 98

4.4.1. Saturated fatty acids $\quad 98$

4.4.2. Monounsaturated fatty acids $\quad 99$

4.4.3. Polyunsaturated fatty acids $\quad 99$

4.5. Seasonal Variation of Quality and Quantity of Fish Lipids 108 in Selected Species

4.5.1. Variation of lipid content 108 
4.5.2. Variation of fatty acids

4.6. Quality Changes of Fish and Fish Lipids During Storage

4.6.1. Changes observed in the quality of fish and fish lipids during storage at room temperature $\left(32^{\circ} \pm 1 \mathrm{C}\right)$

4.6.2. Changes observed in the quality of fish and lipids during ice storage $\left(0^{\circ} \pm 1 \mathrm{C}\right)$

4.6.3. Changes observed in the quality of fish and fish lipids during storage at $-18^{\circ} \pm 1 \mathrm{C}$

4.7. Preservation of Fish Lipids Using Natural Anti-oxidants

4.7.1. Studies on the effect of some natural plant extracts in the preservation of fish lipids

4.7.2 Quantification of preservative action of crude Indian

Gooseberry extract

4.7.3. Evaluation of anti-oxidant activity of Indian gooseberry using different solvent systems to extract active components

4.7.4. Investigation of antioxidant activity of purified compounds from Indian gooseberry

5. CONCLUSIONS

LITEATURE CITED

APPENDIX 


\section{LIST OF TABLES}

Page No

Table-2.1.1 Intramusclar phospholipid distribution of Sucker (Catostomus commersoni).

Table-2.1.2 Comparison between fatty acids of phospholipids and triglycerides in fish species.

Table-2.3.1 Lipid content of principal fish used in fish lipid production.

Table-2.5.1 Cholesterol content in some fish and seafood lipids.

Table-2.6.1 Relative rates of oxidation.

Table-4.1.1 Proximate composition of fish.

Table-4.2.1 Percentage of lipids extracted and its quality

Table-4.2.2 Changes of fatty acids of fish lipids during extraction 91

$\begin{array}{lll}\text { Table-4.3.1 Lipid composition of fish } & 94\end{array}$

Table-4.3.2 Fatty acid composition of lipid classes of White sardinella. 97

$\begin{array}{lll}\text { Table-4.4.1 List of species studied for fatty acid composition. } & 104\end{array}$

$\begin{array}{lll}\text { Table-4.4.2 Fatty acid composition of small pelagics. } & 105\end{array}$

$\begin{array}{lll}\text { Table-4.4.3 Content of fatty acids present in small pelagics. } & 106\end{array}$

Table-4.5.1 Seasonal variation of fatty acid composition of White sardinella 111

$\begin{array}{lll}\text { Table-4.5.2 Seasonal variation of fatty acid composition of Thryssa.sp. } & 112\end{array}$

$\begin{array}{lll}\text { Table-4.6.1.1 Changes observed in the quality of fish during storage at room } & 115\end{array}$ temperature

Table-4.6.1.2 Changes observed in the quality of extracted fish lipids during storage at room temperature 
Table-4.6.2.1 Changes observed in the quality of fish and fish lipids during ice storage.

Table-4.6.3.1 Changes of peroxides, free fatty acids and total volatile nitrogen of fish and fish lipids during storage at $-18^{\circ} \mathrm{C}$.

Table-4.6.3.2 Variation of fatty acid composition of fish during storage at- $18^{\circ} \mathrm{C}$.

Table-4.6.3.3 Variation of fatty acid composition of extracted fish lipids during storage at $-18^{\circ} \mathrm{C}$.

Table-4.7.1.1 Levels of peroxides of fish lipids treated with plant component extracts during storage at $30^{\circ} \mathrm{C}$

Table-4.7.1.2 Levels of free fatty acids of fish lipids treated with plant component extracts during storage at $30^{\circ} \mathrm{C}$

Table-4.7.1.3 Levels of saturated fatty acids of fish lipids treated with Indian Gooseberry $\left(P\right.$. emblica) extract during storage at $30^{\circ} \mathrm{C}$

Table-4.7.1.4 Levels of monounsaturated fatty acids of fish lipids treated with Indian Gooseberry (P. emblica) extract during storage at $30^{\circ} \mathrm{C}$

Table-4.7.1.5 Levels of polyunsaturated fatty acids of fish lipids treated with Indian Gooseberry ( $P$. emblica) extract during storage at $30^{\circ} \mathrm{C}$

Table-4.7.2.1 Levels of peroxides of fish lipids treated with different concentrations of Indian gooseberry during storage at $30^{\circ} \mathrm{C}$

Table-4.7.2.2 Levels of free fatty acids of fish lipids treated with different concentrations of Indian gooseberry during storage at $30^{\circ} \mathrm{C}$

Table-4.7.2.3 Levels of saturated fatty acids of fish lipids treated with different concentrations of Indian gooseberry during storage at $30^{\circ} \mathrm{C}$

Table-4.7.2.4 Levels of monounsaturated fatty acids of fish lipids treated with 139 different concentrations of Indian gooseberry during storage at $30^{\circ} \mathrm{C}$

Table-4.7.2.5 Levels of polyunsaturated fatty acids of fish lipids treated with different concentrations of Indian gooseberry during storage at $30^{\circ} \mathrm{C}$

Table-4.7.3.1 Levels of peroxides in fish lipids during storage with different solvent extracts of Indian Gooseberry. 
Table-4.7.3.2 Levels of free fatty acids in fish lipids during storage with different solvent extracts of Indian Gooseberry.

Table-4.7.3.3 Variation of saturated fatty acids of fish lipids treated with different solvent extracts of Indian gooseberry during storage at $30^{\circ} \mathrm{C}$

Table-4.7.3.4 Variation of monounsaturated fatty acids of fish lipids treated with different solvent extracts of Indian gooseberry during storage at $30^{\circ} \mathrm{C}$

Table-4.7.3.5 Variation of polyunsaturated fatty acids of fish lipids treated with different solvent extracts of Indian gooseberry during storage at $30^{\circ} \mathrm{C}$

Table-4.7.4.1 Levels of peroxides in fish lipids during storage with fractionated Indian gooseberry

Table-4.7.4.2 Levels of free fatty acids in fish lipids during storage with fractionated Indian gooseberry

Table-4.7.4.3 Levels of saturated fatty acids in fish lipids during storage with fractionated Indian gooseberry

Table-4.7.4.4 Levels of monounsaturated fatty acids in fish lipids during storage with fractionated Indian gooseberry

Table-4.7.4.5 Levels of polyunsaturated fatty acids in fish lipids during storage with fractionated Indian gooseberry 


\section{LIST OF FIGURES}

Page No

Figure-2.1.1 Triacylglycerol (Triglyceride) of fish lipids.

Figure-2.2.1 Distribution of total fat in various body parts and organs of mackerel 13 (S. scombrus) and capelin (Mallotus villosus) of Norwegian origin.

Figure-2.5.1 Key steps in conversion of dietary linoleic acid (18:2 n-6) to arachidonic acid (20:4 n-6) and thence to prostanoids and leukotrienes

Figure-2.7.1 Chemical structures of the most commonly used synthetic antioxidants

Figure-2.7.2 Chemical structures of a selection of natural compounds with antioxidant properties

Figure-3.2.1 Temperature variation of the column used in the fatty acid analysis.

Figure-4.1.1 Lipid content of fish

Figure-4.4.1 The relationship between lipid content (\%) and n-3 polyunsaturated fatty acids (\%)

Figure-4.5.1 Seasonal variation of lipid content in White sardinella

Figure-4.5.2 Seasonal variation of lipid content in Thryssa sp

Figure-4.5.3 Seasonal variation of lipid content in Streaked spinefoot

Figure-4.5.4 Seasonal variation of lipid content in Silver belly

Figure-4.7.1.1 Variation of peroxides of fish lipids treated with plant component extracts during storage at $30^{\circ} \mathrm{C}$.

Figure-4.7.1.2 Variation of free fatty acids of fish lipids treated with plant component extracts during storage at $30^{\circ} \mathrm{C}$

Figure-4.7.1.3 Variation of saturated fatty acids of fish lipids treated with Indian gooseberry extract during storage at $30^{\circ} \mathrm{C}$

Figure-4.7.1.4 Variation of monounsaturated fatty acids of fish lipids treated with Indian gooseberry extract during storage at $30^{\circ} \mathrm{C}$

Figure-4.7.1.5 Variation of polyunsaturated fatty acids of fish lipids treated with Indian gooseberry extract during storage at $30^{\circ} \mathrm{C}$ 
Figure-4.7.2.1 Variation of peroxides of fish lipids treated with different concentrations of Indian gooseberry during storage at $30^{\circ} \mathrm{C}$

Figure-4.7.2.2 Variation of free fatty acids of fish lipids treated with different concentrations of Indian gooseberry during storage at $30^{\circ} \mathrm{C}$

Figure-4.7.2.3 Variation of saturated fatty acids of fish lipids treated with different concentrations of Indian gooseberry during storage at $30^{\circ} \mathrm{C}$

Figure-4.7.2.4 Variation of monounsaturated fatty acids of fish lipids treated with different concentrations of Indian gooseberry during storage at $30^{\circ} \mathrm{C}$

Figure-4.7.2.5 Variation of polyunsaturated fatty acids of fish lipids treated with different concentrations of Indian gooseberry during storage at $30^{\circ} \mathrm{C}$

Figure-4.7.3.1 Variation of peroxides of fish lipids treated with different solvent extracts of Indian gooseberry during storage at $30^{\circ} \mathrm{C}$

Figure-4.7.3.2 Variation of free fatty acids of fish lipids treated with different solvent extracts of Indian gooseberry during storage at $30^{\circ} \mathrm{C}$

Figure-4.7.3.3 Variation of saturated fatty acids of fish lipids treated with different solvent extracts of Indian gooseberry during storage at $30^{\circ} \mathrm{C}$

Figure-4.7.3.4 Variation of monounsaturated fatty acids of fish lipids treated with different solvent extracts of Indian gooseberry during storage at $30^{\circ} \mathrm{C}$

Figure-4.7.3.5 Variation of polyunsaturated fatty acids of fish lipids treated with different solvent extracts of Indian gooseberry during storage at $30^{\circ} \mathrm{C}$

Figure-4.7.4.1 Changes in the levels of peroxides in fish lipids during storage with fractionated Indian gooseberry

Figure-4.7.4.2 Changes in the levels of free fatty acids in fish lipids during storage with fractionated Indian gooseberry

Figure-4.7.4.3 Changes in the levels of saturated fatty acids in fish lipids during storage with fractionated Indian gooseberry

Figure-4.7.4.4 Changes in the levels of monounsaturated fatty acids in fish lipids during storage with fractionated Indian gooseberry

Figure-4.7.4.5 Changes in the levels of polyunsaturated fatty acids in fish lipids during storage with fractionated Indian gooseberry 


\section{LIST OF APPENDICES}

Page No

Appendix -1 Chilaw and Negombo fish landing sites in North-Western coast Of Sri Lanka.

Appendix -2 Calibration curve for lipid class analysis

\section{LIST OF PLATES}

Page No

Plate - 1 Gas chromatograph (Shimadzu GC-14A)

Plate - 2 Lipids of White sardinella, Thryssa.sp, Streaked spinefoot and Silver belly developed on TLC plates.

Plate $-3 \quad$ Fish species selected for seasonal variation studies

Plate $-4 \quad$ Fruit of Indian Gooseberry

Plate - 5 Soxhlet extraction of Indian gooseberry 


\section{ACKNOWLEDGEMENTS}

I am grateful to my supervisors Prof. A Bamunuarachchi, Dr. W M K Perera and Dr V K Graffham for their invaluable supervision, guidance and constructive criticism throughout the study.

With great pleasure I wish to thank Dr. M U Jayasekara (former Director General / NARA, Project Manager STD-3) for the invaluable guidance and encouragement for the study.

I would like to thank the European Economic Community (EEC) for the Financial assistance provided under the STD-3 project on Improved Utilization of low value fish species (Research Area III- Fish Lipids, No TS3-CT93-0207) through Food and Agriculture Organization of the United Nations (FAO) and National Aquatic Resources Research \& Development Agency (NARA), Sri Lanka.

I am grateful to Prof. P W Epasinghe (Chairman, NARA), Dr D S Jayakody (Director General, NARA), and Dr. J M P K Jayasinghe (Head / IPHT, NARA) for their encouragement and invaluable help for the study.

I am also thank to Prof. W S Fernando (Dean / Faculty of Applied Science) and Prof. A M Abeyasekara (Head / Dept. of Chemistry) of University of Sri Jayawardenepura for their support and interest for the study.

With great pleasure I acknowledge the support of Mrs. Chamila Jayasinghe, Mrs. R Samaradiwakara, Mrs. K Hettiarachchi, Mr. S Jayasooriya, Mrs C Jayasinghe, Mr. G Wijerathne, Mr. K Jayasena, Mrs. U K Kusumalatha, Miss. M Pathapperuma, Miss. K Chandrani and other staff members of the Institute of Post Harvest Technology, NARA during the work in field and the laboratory. 
I would like to thank Mr. David James (Senior Fishery Industry Officer / FAO), Prof. H H Huss and to Dr. Peter BenEmbarek (STD-3 Research coordination, EEC) for their excellent coordination of the Sri Lankan component as well as the whole STD -3 project among nine participating countries and providing opportunities to participate in a number of international conferences.

I also wish to thank Mr. Hemantha Dassanayake (Head/ Environment Studies Division, NARA), Mr. Ajith Gunarathne (Information Officer / NARA) and Mr. Sunil Amarasekara (Indo Pacific Tuna Program / Sri Lanka) for their invaluable support.

My sincere thanks are also due to Mr. Samantha Thennaskoon (Research Student), Mr. Sisira Weerasinghe (Technical Officer) and Mrs. Asoka Chandrani (Secretary) of Department of Chemistry, University of Sri Jayawardenepura for the kind assistance and also to my friends Lasantha Perera and Amanda Meegama for there valuable help in various ways.

Finally, I wish to thank my dear parents, sisters and loving wife, Nilantha, for the enormous encouragement and this thesis is dedicated to them. 


\title{
COMPOSITION AND STABILITY OF FISH LIPIDS
}

\author{
By
}

E. M.R.K. B. Edirisinghe

\begin{abstract}
Fish lipids are becoming promising food material for human due to their high nutritional and pharmaceutical value. Fish lipids are reported to have high amount of polyunsaturated fatty acid and therefore are different in composition and stability than other lipids. The study was carried out to investigate novel extraction methods, composition, seasonal changes and stability during storage of fish lipids in small pelagics.

The proximate composition of thirty three different small pelagics were studied. On the basis of lipids content, abundance and price of fish species, four pelagics were selected for further studies. These were White sardinella, Thryssa.sp, Silver belly and Streaked sprinefoot. Extraction of fish lipids was carried out by four different methods. i.e. acid silage, microbial silage, wet rendering and steaming using White sardinella. Of the methods evaluated the most efficient extraction method was acid silage extraction which provided $73 \%$ of the total lipids and $52 \%$ of total lipids was extracted by steaming compared to the yield from Bligh \& Dyer method.

The selected four fish species from different families showed different types of lipid composition. The triacyl glycerols contributed to the major proportion of lipids in three species. The complex polar lipids was the largest lipid class only in streaked spinefoot, contributing $38 \%$ from total lipids. Separation of cholesterol from 1,3 diacyl glycerol was difficult by the solvent system. Fatty acid profile of individual lipid classes were different
\end{abstract}


from each other. Polar lipid fraction of white sardinella lipids consisted with higher amount of polyunsaturated fatty acids than the triacyl glycerol fraction of the same fish lipid.

The study when extended to fatty acid assay of forty fish species revealed that the percentage of omega-3 polyunsaturated fatty acids were high in Yellowstripe scad (Selaroides leptolepis), Dorab-wolf herring (Chirocentrus dorab), Spotted sardinella (Amblygaster sirm), Blacktip sardinella (Sardinella melanura), Buccaneer anchovy (Stolephorus punctifer), Brushtooth lizard fish (Saurida undosquamis) and Big-eye barracuda. However, these species contributed low amounts of these acids due to the low fat content present in them. White sardinella and Thryssa.sp showed the highest amount of lipids during the months of November and February whereas the month of May was the lowest level. Relatively low amounts were found in Silver belly and Streaked sprinefoot with no marked seasonal peaks or troughs. In general, the lipids content was low during the period April -June due to the spawning season of most species.

Influence of temperature $\left(32,0\right.$ and $\left.-18^{\circ} \mathrm{C}\right)$ on the quality of fish and fish lipids was studied using White sardinella. Oxidation was very rapid when stored at room temperature $\left(32^{\circ} \mathrm{C}\right)$; ice storage $\left(0^{\circ} \mathrm{C}\right)$ maintained good quality over a period of one month; freezing $\left(-18^{\circ} \mathrm{C}\right)$ considerably slowed down undesirable quality changes. During the 446 days storage period, the omega-3 PUFA content slightly decreased.

When the antioxidant property of some plant extracts in relation to rancidity was taken into consideration, Indian Gooseberry (Nelli, Phynanthus emblica) showed the ability to offer highest protection for fish lipids. Active components in Indian Gooseberry, when extracted using Ethanol instead of other organic solvents and water, produced more efficient results. Furthermore, the ethanolic extract was separated using different solvents with different polarity and the best activity was recorded in ethyl acetate system. This system recorded higher activity at $1000 \mathrm{ppm}$ compared to $200 \mathrm{ppm}$ of BHT. 